\title{
Pengaruh Media Tanam dan Penggunaan Mol Bonggol Pisang terhadap Pertumbuhan Bibit Kakao (Theobroma cacao L.)
}

(The Effect of Plant Medium and Local Microorganism Banana Tuber on the Growth of Cocoa Seedling (Theobroma cacao L.)

\author{
Datul Fadillah $^{1}$, Trisda Kurniawan, Erida Nurahmi ${ }^{*}$ \\ ${ }^{1}$ Program Studi Agroteknologi, Fakultas Pertanian, Universitas Syiah Kuala
}

\begin{abstract}
Abstrak. Penelitian ini bertujuan untuk mengetahui pengaruh perbandingan media tanam dan beberapa konsentrasi mikroorganisme lokal terhadap pertumbuhan bibit kakao. Penelitian ini dilaksanakaan di Kebun Percobaan 2 dan Labaratorium Hortikultura, Jurusan Agroteknologi Fakultas Pertanian Universitas Syiah Kuala, Banda Aceh dari bulan Juli sampai Oktober 2018. Penelitian ini menggunakan Rancangan Acak Kelompok pola faktorial 4 x 4 dan 3 ulangan, sehingga terdapat 48 satuan percobaan dan dilanjutkan dengan uji Beda Nyata Jujur taraf 5\% pada hasil uji F yang signifikan. Faktor pertama adalah perbandingan media tanam dengan 4 taraf yaitu: kontrol-2 tanah : 1 pupuk kandang $\left(\mathrm{M}_{0}\right), 2$ tanah : pupuk kandang : 1 sekam bakar $\left(\mathrm{M}_{1}\right), 1$ tanah : 2 pupuk kandang : 1 sekam bakar $\left(\mathbf{M}_{2}\right), 1$ tanah : 1 pupuk kandang : 2 sekam bakar $\left(\mathrm{M}_{3}\right)$. Faktor kedua adalah konsentrasi mol bonggol pisang dengan 4 taraf yaitu 0, 10\%, 20\% dan 30\% $\mathrm{L}^{-1}$ air. Parameter yang diamati adalah tinggi bibit, diameter pangkal batang, jumlah daun, berat berangkasan basah dan berat berangkasan kering. Hasil penelitian menunjukkan bahwa, perlakuan perbandingan media tanam berpengaruh tidak nyata terhadap semua parameter. Pemberian beberapa konsentrasi mikroorganisme lokal berpengaruh nyata terhadap jumlah daun bibit kakao umur 8 MST dan berpengaruh sangat nyata pada jumlah daun bibit kakao umur 12 MST. Terdapat interaksi yang nyata antara perlakuan media tanam $\mathrm{M}_{0}$ dan konsentrasi mol $20 \%\left(\mathrm{M}_{2}\right)$.
\end{abstract}

Kata Kunci: Bibit kakao, Media tanam dan Mol,

Abstract. The purposes of this research were to know the effect of comparison media planting and several concentrations of local microorganism on the growth of cocoa seedlings. This research was conducted at Experimental Garden 2 and Horticulture Laboratory, Department of Agrotechnology, Faculty of Agriculture Syiah Kuala University, Banda Aceh from July to October 2018. This study used a Randomize Block Design of $4 \times 4$ factorial pattern with 3 replication, so that were 48 experimental units and continued with a Honestly Significance Difference 5\% level on significant F test result. The first factor is the comparison medium planting of 4 levels : control- 2 soil : 1 manure $\left(\mathrm{M}_{0}\right)$, 2 soil : 1 manure : 1 hueks fuel $\left(M_{1}\right), 1$ soil : 2 manure : 1 hueks fuel $\left(M_{2}\right)$ and 1 soil : 1 manure : 2 hueks fuel $\left(M_{3}\right)$. The second factor is the concentration of local microorganism of 4 levels: $0\left(\mathrm{P}_{0}\right), 10 \%\left(\mathrm{P}_{1}\right), 20 \%\left(\mathrm{P}_{2}\right)$ and $30 \%$ $\left(\mathrm{P}_{3}\right) \mathrm{L}^{-1}$ water. Parameters observed were plant height, stem base diameter, number of leaves, wet weight and dry weight. The result showed that the treatment of comparison planting medium had unsignificantly effect on all parameters. Consentrations of local microorganinism has a significant effect on the number of leaves of cocoa seedlings aged $8 \mathrm{WAP}$ and has a very significantly effect on the number of leaves cocoa seedlings aged 12 WAP. There is significantly effect between the treatment of comparison planting medium control-2 tanah : 1 pupuk kandang $\left(\mathrm{M}_{0}\right)$, and local microorganism concentrations $20 \%\left(\mathrm{P}_{2}\right)$.

Keyword : Media planting, Local microorganism, Cocoa seeds.

\section{PENDAHULUAN}

Tanaman Kakao (Theobroma cacao L.) berasal dari negara di Amerika Tengah dan Amerika Selatan (bagian utara). Di Indonesia tanaman kakao pertama kali berkembang di daerah Minahasa (Sulawesi Utara) yang diperkenalkan oleh orang 
Spanyol pada tahun 1560 dan terus menyebar hingga ke berbagai wilayah di Indonesia (Pusat Penelitian Kopi dan Kakao Indonesia, 2004).

Salah satu usaha yang perlu diperhatikan dalam upaya peningkatan produktivitas kakao yaitu dengan memperhatikan pembibitan tanaman kakao. Usaha pembibitan yang baik diharapkan mampu mendapatkan bahan tanam yang mempunyai tingkat produktivitas yang tinggi dan memberikan kualitas hasil yang baik (Siregar et al., 2004). Untuk memperbaiki permasalahan diatas, membutuhkan pengembangan tanaman kakao sejak dalam masa pembibitan dapat diberikan perlakuan media tanam. Menurut Hakim et al. (2005) media tanam yang cukup bahan organik mampu meningkatkan pertumbuhan tanaman dibandingkan dengan media tanam yang kurang bahan organik. Kondisi fisik tanah menentukan penetrasi akar kedalam tanah, penyerapan air, drainase, aerasi dan nutrisi tanaman. Sifat-sifat fisik tanah tergantung pada jumlah, ukuran, bentuk, susunan komposisi mineral dari partikel- partikel tanah, bahan organik, jumlah bahan organik, volume dan bentuk pori-pori serta perbandingan air dan udara yang menempati pori-pori waktu terbentuk.

Untuk mencukupi kebutuhan hara yang dibutuhkan oleh tanaman kakao maka perlu adanya bahan tambahan dari luar, salah satunya seperti pupuk cair dari Mikroorganisme lokal. Menurut Sisworo (2006), bahan organik memiliki peranan penting sebagai penghasil energi yang dapat mendukung kehidupan dan berkembangbiaknya berbagai jenis mikroorganisme tanah. Kekurangan bahan organik menyebabkan mikroorganisme tanah mengalami penuruanan. Kekurangan tersebut dapat diperbaiki dengan penambahan mol, seperti yang telah disebutkan oleh Purwasasmita (2009), mikroorganisema lokal merupakan larutan hasil fermentasi yang bahan dasarnya didapatkan dari sumber daya yang tersedia, mengandung unsur hara makro dan mikro serta mikroorganisme yang dapat berfungsi sebagai perombak bahan organik, merangsang pertumbuhan dan menjadi agen pengendali hama dan penyakit tanaman sehingga dapat digunakan sebagai dekomposer, pupuk hayati, dan pestisida organik.

Mikroorganisme lokal dari bonggol pisang dapat menjadi alternatif yang dapat berperan dalam masa pertumbuhan vegetative dan dapat membuat tanaman lebih tahan terhadap penyakit. Kandungan asam fenolat yang tinggi berfungsi untuk mengikat ionion $\mathrm{Fe}$. A, dan $\mathrm{Ca}$ sehingga membantu tersedianya $\mathrm{P}$ tanah yang dapat membantu proses terbentuknya bunga dan buah (Setyaninggsih et al., 2009). Berdasarkan penelitian yang telah dilakukan oleh Oktiningtyas (2015), Pemupukan dengan mol bonggol pisang dan kulit pisang berpengaruh pada pertumbuhan selada dengan peubah panjang batang, jumlah daun, dan lebar daun. Sedangkan hasil penelitian Tarigan et al. (2014) pengaplikasian pupuk organic cair dari mol bonggol pisang dosis $0,15,30$ dan $45 \mathrm{cc} \mathrm{L}^{-1}$ air berbeda tidak nyata terhadap semua parameter. Berdasarkan uraian diatas maka perlu dilakukan penelitian tentang perbandingan media tanam dan penggunaan konsentrasi Mikroorganisme lokal yang tepat pada saat pembibitan kakao.

Pengaruh Media Tanam dan Penggunaan Mol Bonggol Pisang terhadap Pertumbuhan Bibit Kakao (Theobroma cacao L.) (Datul Fadillah, Trisda Kurniawan, Erida Nurahmi) 


\title{
METODE PENELITIAN
}

Penelitian ini dilaksanakan di Kebun Percobaan 2 dan Laboratorium Hortikultura, Fakultas Pertanian Universitas Syiah Kuala, Darussalam-Banda Aceh, dimulai dari bulan Juli sampai Oktober 2018.

\begin{abstract}
Alat
Alat yang digunakan dalam penelitian ini antara lain : polybag dengan ukuran dalam keadaan terlipat $20 \mathrm{~cm} \times 30 \mathrm{~cm}$ atau isi $5 \mathrm{~kg}$, ayakan, paranet sebagai naungan, cangkul, gembor, meteran, jangka sorong, jirigen untuk wadah pembuatan mol, botol minuman bekas, timbangan digital, oven, kamera dan alat-alat lain yang diperlukan.
\end{abstract}

\section{Bahan}

Bahan yang digunakan dalam penelitian ini berupa benih kakao klon MCC 01 sebanyak 144 benih yang diperoleh dari kebun petani di Desa Puduek, Kecamatan Trienggadeng, Kabupaten Pidie Jaya, tanah, pupuk kandang, sekam bakar, abu sekam, $6 \mathrm{~kg}$ bonggol pisang, $1.2 \mathrm{~kg}$ gula merah, 12 liter air cucian beras dan fungisida Dithane M-45.

\section{Metode Penelitian}

Penelitian ini menggunakan Rancangan Acak Kelompok (RAK) pola faktorial 4 $\times 4$ dengan 3 ulangan. Faktor pertama terdiri atas 4 taraf yaitu perbandingan media tanam (M), Kontrol (tanah), Tanah : Pupuk kandang : Sekam bakar (2:1:1), Tanah : Pupuk kandang : Sekam bakar (2:1:1) dan Tanah : Pupuk Kandang : Sekam bakar $(1: 1: 2)$ dan faktor kedua yaitu konsentrasi $\mathrm{Mol}(\mathrm{P})$ terdiri atas 4 taraf $0\left(\mathrm{P}_{0}\right), 10 \%\left(\mathrm{P}_{1}\right)$, $20 \%\left(\mathrm{P}_{2}\right)$ dan $30 \%\left(\mathrm{P}_{3}\right)$, sehingga diperoleh 16 kombinasi perlakuan dan 48 unit percobaan.

\section{Pelaksanaan Penelitian Persiapan Media Penyemaian}

Benih kakao disemai pada karung goni yang telah dibasahkan dengan air. Karung goni yang dipakai adalah karung goni yang terbuat dari serat kayu.

\section{Persemaian}

Benih disemai pada karung goni yang telah dibasahkan, disusun dengan rapi agar tidak mengganggu pertumbuhan akar antar benih. Setelah disusun rapi kemudian ditutup dengan menggunakan karung basah. Satu hari sekali karung goni disiram agar terjaga kelembabannya.

\section{Persiapan Media Tanam}

Media tanam yang digunakan sesuai dengan perbandingan taraf perlakuan :

$\mathrm{M}_{0}$ : Tanah : Pupuk Kandang (2:1, kontrol)

$\mathrm{M}_{1}$ : Tanah : Pupuk kandang : Sekam bakar $(2: 1: 1)$

$\mathrm{M}_{2}$ : Tanah : Pupuk Kandang : Sekam bakar (1:2:1)

$\mathrm{M}_{3}$ : Tanah : Pupuk Kandang : Sekam bakar (1:1:2) 

perlakuan.

Media tanam dimasukkan kedalam polybag dan diberi label sesuai dengan

\section{Penanaman}

Pada saat benih telah berkecambah sekitar 3 hari atau setelah benih mempunyai radikula, kemudian dipindahkan kedalam media tanam yang telah dipersiapkan. Polybag yang digunakan adalah polybag dengan ukuran $20 \mathrm{~cm}$ x $30 \mathrm{~cm}$ atau isi $5 \mathrm{~kg}$. Diisi dengan media tanam berupa campuran tanah, pupuk kandang, dan sekam bakar yang telah diayak dengan perbandingan sesuai taraf perlakuan, media tanam diberikan berdasarkan volume. Setelah benih dipindahkan kedalam media tanam, polybag disusun sesuai dengan bagan percobaan di bawah naungan yang sudah disiapkan.

\section{Pemeliharaan}

Pemeliharaan bibit tanaman kakao meliputi penyiraman, penyulaman, dan penyiangan.

\section{Pemberian Mol}

Pemberian mol dilakukan tiga kali sesuai dengan perlakuan yaitu 10\%, 20\% dan $30 \%$ dengan interval waktu 3 minggu sekali. Pemberian mol pertama yaitu dua minggu setelah tanam, lima minggu setelah dan delapan minggu setelah tanam. Aplikasi mol dllakukan dengan cara sebagai berikut :

1. Mol dengan masing-masing konsentrasi perlakuan $10 \%, 20 \%$ dan $30 \%$ diencerkan dengan satu liter air.

2. Setelah diencerkan mol diaplikasikan pada bibit dengan cara disiram pada daerah panggal batang bibit sebanyak $200 \mathrm{ml}$.

\section{Pengamatan}

Pengamatan yang dilakukan meliputi tinggi tanaman, diameter panggal batang dan jumlah daun yang diamati pada pada yaitu 4 MST, 8 MST dan 12 MST. Jumlah berangkasan basah dan jumlah berangkasan kering pada 12 MST setelah dilakukan pembongkaran.

\section{HASIL DAN PEMBAHASAN}

\section{Pengaruh Media Tanam terhadap Pertumbuhan Bibit Kakao}

Hasil uji $\mathrm{F}$ pada analisisis ragam menunjukkan bahwa, perbandingan media tanam berpengaruh tidak nyata terhadap semua parameter yang diamati.

Tabel 1 menunjukkan bahwa, tinggi tanaman, diameter pangkal batang, jumlah daun, berat berangkasan basah dan berat berangkasan kering pada perlakuan perbandingan media tanam berbeda tidak nyata, akan tetapi pertumbuhan bibit kakao cenderung lebih baik pada pemberian media tanam kontrol 2 tanah : 1 pupuk kandang $\left(\mathrm{M}_{0}\right)$.

Dari beberapa perbandingan media tanam yang dicobakan, pertumbuhan bibit kakao terbaik cenderung dijumpai pada media tanam tanah dan pupuk kandang $(2: 1)$ kontrol $\left(\mathrm{M}_{0}\right)$. Hal ini diduga pada media tanam tanah dan pupuk kandang telah dapat 
menyediakan unsur hara bagi tanaman sehingga dapat mempengaruhi struktur tanah yang akan memacu pertumbuhan tanaman. Hal tersebut sejalan dengan penelitian yang telah dilakukan oleh Winaldy et al. (2016), penggunaan media tanam tanah dan pupuk kandang dengan perbandingan 2:1 dapat meningkatkan rataan tinggi tanaman, berat basah tajuk dan jumlah daun pada umur tanaman 90 HST. Agustina (1990) menyatakan bahwa pemberian pupuk kandang pada media tanam dapat memberikan peningkatan ketersediaan unsur hara $\mathrm{N}$ yang sangat mempengaruhi pertumbuhan jumlah daun, panjang akar dan diameter pangkal batang.

Tabel 1. Rata-rata pertumbuhan bibit kakao akibat perlakuan berbagai media tanam

\begin{tabular}{lcccc}
\hline \multirow{2}{*}{\multicolumn{1}{c}{ Parameter }} & \multicolumn{3}{c}{ Media Tanam } \\
\cline { 2 - 5 } & $\begin{array}{c}\text { Kontr } \\
\text { ol } \\
\left(\mathrm{M}_{0}\right)\end{array}$ & $\begin{array}{c}1: 1: 2 \\
\left(\mathrm{M}_{1}\right)\end{array}$ & $\begin{array}{c}1: 2: 1 \\
\left(\mathrm{M}_{2}\right)\end{array}$ & $\begin{array}{c}1: 1: 2 \\
\left(\mathrm{M}_{3}\right)\end{array}$ \\
\hline Tinggi Bibit 4 MST (cm) & 13.64 & 14.33 & 14.00 & 14.11 \\
Tinggi Bibit 8 MST (cm) & 17.17 & 16.75 & 16.58 & 16.55 \\
Tinggi Bibit 12 MST (cm) & 20.97 & 20.75 & 20.36 & 19.62 \\
Diameter Pangkal Batang 4 MST (mm) & 2.54 & 2.38 & 2.56 & 2.45 \\
Diameter Pangkal Batang 8 MST (mm) & 4.39 & 4.29 & 4.10 & 4.24 \\
Diameter Pangkal Batang 12 MST(mm) & 5.21 & 4.90 & 4.79 & 4.95 \\
Jumlah Daun 4 MST (helai) & 4.45 & 3.83 & 3.64 & 4.11 \\
Jumlah Daun 8 MST (helai) & 9.00 & 9.33 & 9.19 & 8.94 \\
Jumlah Daun 12 MST (helai) & 19.03 & 17.17 & 17.86 & 17.05 \\
Berat Berangkasan Basah (g) & 12.59 & 11.99 & 12.58 & 11.95 \\
Berat Berangkasan Kering (g) & 3.69 & 3.34 & 3.45 & 3.36 \\
\hline
\end{tabular}

Sekam bakar mampu memperbaiki struktur tanah, dapat merubah kapasitas tanah, menahan dan melalukan air, serta dapat memperbaiki kemampuan tanah dalam memegang air. Hasil penelitian Kurnia et al. (2017) menjelaskan bahwa dosis sekam bakar terbaik untuk meningkatkan pertumbuhan bibit tanaman kakao yaitu dosis $6 \%$. Penggunaan arang sekam 6\% mampu menghasilkan tinggi bibit $30.26 \mathrm{~cm}$, jumlah daun 20.40 helai dan nisbah tajuk/akar 5.64\%.

Dalam penelitian ini penggunaan sekam bakar dengan perbandingan 2:1:1 (tanah : pupuk kandang : sekam bakar), 1:2:1 (tanah : pupuk kandang : sekam bakar) dan 1:1:2 (tanah: pupuk kandang : sekam bakar). Hal ini diduga penggunaan sekam bakar dalam jumlah yang banyak dapat menghambat pertumbuhan bibit kakao. Seiring dengan penelitian Zalfahri et al. (2017) menyatakan bahwa penggunaan sekam bakar dengan perbandingan 1:2 (tanah : sekam bakar) dan 1:3 (tanah : sekam bakar) memberikan pertumbuhan yang kurang baik untuk bibit tanaman kakao karena media tanam dengan campuran arang sekam yang terlalu banyak dapat menyebabkan media tanam terlalu basah dan banyak mengandung air. Hal tersebut sesuai dengn syarat tumbuh tanaman kakao yang tidak menghendaki adanya air tergenang (Pusat Penelitian Kopi dan Kakao Indonesia, 2004), Kelebihan air pada media tanam kakao akan menyebabkan pembusukan akar dan mengganggu fisiologis tanaman kakao.

Sekam bakar dapat menjadi salah satu bahan pembenah tanah sintetis (alami)

Pengaruh Media Tanam dan Penggunaan Mol Bonggol Pisang terhadap Pertumbuhan Bibit Kakao (Theobroma cacao L.) (Datul Fadillah, Trisda Kurniawan, Erida Nurahmi) 
dapat berupa organik atau mineral yang berbentuk padat dan mampu memperbaiki sifat fisik, kimia dan biologi tanah (Permentan, 2011). Hasil penelitian menunjukkan bahwa perlakuan $\mathrm{M}_{1}, \mathrm{M}_{2}$ dan $\mathrm{M}_{3}$ memberikan hasil yang kurang baik dibandingkan perlakuan $\mathrm{M}_{0}$, hal tersebut membuktikan bahwa peningkatan dosis arang sekam dapat menyebabkan penurunan biomassa dan hasil tanaman. Penurunan tersebut terjadi karena menurunnya ketersediaan $\mathrm{N}$ bagi tanaman sebagai akibat adanya imobilisasi $\mathrm{N}$ yang dipicu oleh peningkatan aktivitas mikroba karena adanya suplai $\mathrm{C}$ labil dari senyawa-senyawa dalam volatil arang sekam serta adanya kandungan senyawa dalam bahan volatil yang bersifat toksik bagi tanaman (Gale et al., 2016).

\section{Pengaruh Konsentrasi Mol terhadap Pertumbuhan Bibit Kakao}

Tabel 2 menunjukkan bahwa, jumlah daun bibit kakao umur 8 MST pada konsentrasii mol 0\% $\left(\mathrm{M}_{0}\right)$ menghasilkan jumlah daun tertinggi 9.99 helai yang berbeda nyata dengan perlakuan konsentrasi mol $10 \%\left(\mathrm{M}_{1}\right)$ namun tidak berbeda nyata dengan dosis $30 \%\left(\mathrm{M}_{3}\right)$ dan $20 \%\left(\mathrm{M}_{2}\right)$. Pada umur 12 MST rata-rata jumlah daun bibit tanaman kakao pada perlakuan konsentrasi mol 30\% $\left(\mathrm{P}_{3}\right)$ menghasilkan jumlah daun tertinggi 20.39 helai yang berbeda nyata dengan perlakuan konsentrasi mol $0 \%\left(\mathrm{P}_{0}\right)$, $10 \%\left(\mathrm{P}_{1}\right)$, dan $20 \%\left(\mathrm{P}_{2}\right)$.

Tabel 2. Rata-rata pertumbuhan bibit kakao akibat konsentrasi Mol

\begin{tabular}{|c|c|c|c|c|c|}
\hline \multirow{2}{*}{$\begin{array}{l}\left.\text { Konsentrasi Mol ( } \mathrm{L}^{-1} \text { air }\right) \\
\text { Parameter }\end{array}$} & & & & & \multirow[b]{2}{*}{$\begin{array}{l}\text { BNJ0,0 } \\
5\end{array}$} \\
\hline & $\begin{array}{l}0 \\
\left(\mathrm{P}_{0}\right)\end{array}$ & $\begin{array}{l}10 \% \\
\left(\mathrm{P}_{1}\right)\end{array}$ & $\begin{array}{l}20 \% \\
\left(\mathrm{P}_{2}\right)\end{array}$ & $\begin{array}{l}30 \% \\
\left(\mathrm{P}_{3}\right)\end{array}$ & \\
\hline$\overline{\text { Tinggi Bibit } 4 \text { MST }(\mathrm{cm})}$ & 14.39 & 13.50 & 13.39 & 14.81 & - \\
\hline Tinggi Bibit 8 MST (cm) & 16.83 & 16.30 & 16.81 & 17.11 & - \\
\hline Tinggi Bibit 12 MST (cm) & 20.56 & 20.69 & 20.47 & 19.98 & - \\
\hline Diameter Pangkal Batang 4 MST (mm) & 2.58 & 2.37 & 2.47 & 2.51 & - \\
\hline Diameter Pangkal Batang 8 MST (mm) & 4.16 & 4.39 & 4.16 & 4.43 & - \\
\hline Diameter Pangkal Batang 12 MST & & & & & \\
\hline$(\mathrm{mm})$ & 4.85 & 4.90 & 4.89 & 5.23 & - \\
\hline Jumlah Daun 4 MST (helai) & 3.75 & 3.97 & 3.61 & 3.61 & - \\
\hline Jumlah Daun 8 MST (helai) & $9.99 \mathrm{~b}$ & $8.00 \mathrm{a}$ & $8.77 \mathrm{ab}$ & $9.69 \mathrm{ab}$ & 1.81 \\
\hline Jumlah Daun 12 MST (helai) & $17.92 \mathrm{~b}$ & $15.42 \mathrm{a}$ & $17.39 \mathrm{ab}$ & $20.39 c$ & 2.41 \\
\hline Berat Berangkasan Basah (g) & 12.79 & 10.85 & 12.65 & 13.06 & - \\
\hline Berat Berangkasan Kering (g) & 3.55 & 2.97 & 3.55 & 3.77 & - \\
\hline
\end{tabular}

Keterangan : Angka yang diikuti oleh huruf yang sama pada baris yang sama berbeda tidak nyata pada taraf 0.05 (Uji BNJ)

Hasil uji $\mathrm{F}$ pada analisis ragam menunjukkan bahwa perbedaan konsentrasi mol berpengaruh sangat nyata untuk parameter jumlah daun pada umur 8 dan 12 MST dan berpengaruh tidak nyata untuk parameter jumlah daun umur 4 MST, tinggi bibit umur 4, 8 dan 12 MST, diameter pangkal batang umur 4, 8 dan 12 MST, berat berangkasan basah umur 12 MST dan berat berangksan kering pada umur 12 MST.

Pengaruh Media Tanam dan Penggunaan Mol Bonggol Pisang terhadap Pertumbuhan Bibit Kakao (Theobroma cacao L.) (Datul Fadillah, Trisda Kurniawan, Erida Nurahmi) 
Tinggi bibit kakao terbaik dijumpai pada perlakuan konsentrasi mol $10 \%\left(\mathrm{P}_{1}\right)$, yang menghasilkan bibit bibit kakao tertinggi $20.69 \mathrm{~cm}$ pada umur $12 \mathrm{MST}$. Hal ini karena konsentrasi mol 10\% $\left(\mathrm{P}_{1}\right)$ merupakan konsentrasi terbaik yang dapat memenuhi kebutuhan unsur hara pada bibit tanaman kakao fase pembibitan. Berdasarkan hasil analisis Mol kandungan hara tertinggi terdapat pada unsur $\mathrm{K}(2.06 \%)$ yang dapat mendukung pertambahan tinggi bibit. Peranan unsur kalium dalam fase pembibitan tanaman dapat meningkatkan pertumbuhan jaringan meristem, memperkuat tegaknya batang dan pada fase generatif dapat memperbaiki ukuran serta kualitas buah (Sidabutar et al., 2013).

Pada parameter diameter pangkal batang terbesar dijumpai pada perlakuan konsentrasi mol $30 \%\left(\mathrm{P}_{3}\right)$ yang menghasilkan diameter terbesar yaitu $5.23 \mathrm{~mm}$ pada umur 12 MST. Hal ini diduga karena adanya pengaruh dari unsur K yang ada pada mol. Hal tersebut terbukti dengan hasil analisis mikroorganisme lokal menunjukkan unsur hara K sebesar $2.06 \%$. Adanya unsur hara Kalium dapat meningkatkan kekuatan batang dan juga menambah daya tahan tanaman terhadap penyakit karena dinding sel tanaman semakin tebal. Jika kekurangan unsur $\mathrm{K}$ dapat menyebabkan melemahnya batang sehingga tanaman mudah rebah (Ruhnayat, 2007).

Pemberian mol dengan konsentrasi $30 \%\left(\mathrm{P}_{3}\right)$ berpengaruh nyata pada umur pada 8 MST menghasilkan rata-rata jumlah daun 9.99 helai dan berpengaruh sangat nyata 12 MST menghasilkan rata-rata 22.39 helai Hal ini diduga karena konsentrasi mol $30 \%$ $\left(\mathrm{P}_{3}\right)$ memiliki kandungan unsur hara $\mathrm{N}$ yang tinggi. Unsur hara $\mathrm{N}$ termasuk hara esensial yang berperan dalam pembentukan daun pada bibit tanaman kakao. Hal ini sesuai dengan pendapat Lindawati, et al. (2000) Nitrogen diperlukan untuk memproduksi protein, lemak dan berbagai senyawa organik lainnya. nitrogen penting dalam hal pembentukan hijau daun yang berguna dalam proses fotosintesis.

Pemberian mol tidak berpengaruh nyata terhadap parameter berat berangkasan basah namun berat tertinggi cenderung diperoleh pada konsentrasi mol 30\% $\left(\mathrm{P}_{3}\right)$ pada umur 12 MST dengan berat berangkasan basah $13.06 \mathrm{~g}$. Tinggi atau rendahnya berat berangkasan basah tanaman tergantung pada tingkat serapan unsur hara yang berlangsung selama proses pertumbuhan tanaman (Satyawibawa dan Widyastuti, 1992). Hal ini diduga pemberian mol dengan konsentrasi $30 \%\left(\mathrm{P}_{3}\right)$ memberikan unsur hara yang cukup dan dapat dimanfaatkan dengan baik oleh bibit kakao.

Pada parameter berat berangkasan kering pemberian mol berpengaruh tidak nyata namun berat berangkasan kering terberat dijumpai pada perlakuan konsentrasi mol 30\% $\left(\mathrm{P}_{3}\right)$ yaitu sebesar $3.77 \mathrm{~g}$. Berat terbaik pada perlakuan konsentrasi mol 30\% $\left(\mathrm{P}_{3}\right)$ diduga karena pada mol yang digunakan sudah terdapat unsur hara yang cukup untuk diserap tanaman terutama unsur K. Geovani (2008) menyatakan bahwa unsur Kalium berperan dalam proses membuka dan menutupnya stomata, mengurangi kerontokan daun bunga dan buah serta dapat dapat meningkatkan bobot kering bibit tanaman kakao.

\section{Pengaruh Interaksi antara Media Tanam dan Konsentrasi Mol terhadap Pertumbuhan Bibit Kakao}

Hasil uji $\mathrm{F}$ pada analisis ragam menunjukkan bahwa terdapat interaksi yang nyata antara media tanam dengan konsentrasi mol terhadap jumlah daun bibit kakao 
umur 12 MST. Rata-rata jumlah daun bibit tanaman kakao umur 12 MST pada berbagai media tanam dan konsentrasi mol setelah diuji dengan $\mathrm{BNJ}_{0.05}$ disajikan pada Tabel 3 .

Tabel 4 menunjukkan bahwa perbandingan media tanam kontrol ( 2 tanah : 1 pupuk kandang) $\mathrm{M}_{0}$ menghasilkan jumlah daun bibit kakao terbanyak pada penggunaan konsentrasi mol 20\% $\left(\mathrm{P}_{2}\right)$ yang berbeda nyata dengan jumlah daun bibit kakao perlakuan konsentrasi mol kontrol $\left(\mathrm{P}_{0}\right), 10 \%\left(\mathrm{P}_{1}\right)$ dan $30 \%\left(\mathrm{P}_{3}\right)$. Perbandingan media tanam $\mathbf{M}_{1}, \mathrm{M}_{2}$ dan $\mathrm{M}_{3}$ menghasilkan jumlah daun bibit kakao terbanyak pada penggunaan konsentrasi mol $30 \%\left(\mathrm{P}_{3}\right)$ yang tidak berbeda nyata dengan jumlah daun bibit kakao perlakuan konsentrasi mol kontrol $\left(\mathrm{P}_{0}\right), 10 \%\left(\mathrm{P}_{1}\right)$ dan $20 \%\left(\mathrm{P}_{2}\right)$.

Kombinasi perlakuan terbaik dijumpai pada perlakuan komposisi media tanam kontrol (2 tanah : 1 pupuk kandang) atau $\left(\mathrm{M}_{0}\right)$ dengan konsentrasi mol $20 \%\left(\mathrm{P}_{2}\right)$ yaitu $\mathrm{M}_{0} \mathrm{P}_{2}$ sebesar

22.56 helai, yang hanya berbeda nyata dengan perlakuan $\mathrm{M}_{3} \mathrm{P}_{3}$ namun tidak berbeda nyata dengan kombinasi perlakuan lainnya.

Tabel 3. Rata-rata jumlah daun bibit kakao umur 12 mst pada berbagai media tanam dan konsentrasi mol

\begin{tabular}{|c|c|c|c|c|c|c|}
\hline \multirow[t]{2}{*}{ Parameter } & \multirow{2}{*}{$\begin{array}{l}\text { Konsentras } \\
\text { Mol } \\
\left(\mathrm{L}^{-1} \text { air }\right)\end{array}$} & \multicolumn{4}{|c|}{ Media Tanam } & $\mathrm{BNJ}$ \\
\hline & & $\mathrm{M}_{0}$ & $\mathrm{M}_{1}$ & $\mathrm{M}_{2}$ & $\mathrm{M}_{3}$ & \\
\hline Jumlah & $\mathrm{P}_{0}$ & $18.56 \mathrm{Aa}$ & $18.00 \mathrm{Aa}$ & $18.89 \mathrm{ABa}$ & 16.22 Aa & \\
\hline $\begin{array}{l}\text { Daun } 12 \\
\text { MST }\end{array}$ & $\begin{array}{l}\mathrm{P}_{1} \\
\mathrm{P}_{2} \\
\mathrm{P}_{3}\end{array}$ & $\begin{array}{l}15.44 \mathrm{Aa} \\
22.56 \mathrm{Bb} \\
19.55 \mathrm{ABa}\end{array}$ & $\begin{array}{l}16.67 \mathrm{Aa} \\
15.34 \mathrm{Aa} \\
18.66 \mathrm{Aa}\end{array}$ & $\begin{array}{l}16.11 \mathrm{Aa} \\
15.34 \mathrm{Aa} \\
21.11 \mathrm{Ba}\end{array}$ & $\begin{array}{l}13.44 \mathrm{Aa} \\
16.33 \mathrm{Aa} \\
22.22 \mathrm{Ba}\end{array}$ & 1.25 \\
\hline
\end{tabular}

Keterangan : Angka yang diikuti oleh huruf yang sama berbeda tidak nyata pada taraf $\mathrm{BNJ}_{0.05}$. Huruf Kapital merupakan notasi horizontal, huruf kecil merupakan notasi vertikal.

Interaksi antara media tanam dengan penggunaan mol sangat nyata pada parameter jumlah daun bibit kakao $12 \mathrm{MST}$.Terdapat interaksi antara perlakuan media tanam 2 tanah : 1 pupuk kandang $\left(\mathrm{M}_{0}\right)$ dan konsentrasi mol 20\% $\left(\mathrm{P}_{2}\right)$ memberikan jumlah daun tertinggi yaitu 22.56 helai. Hal ini diduga bahwa kombinasi antara media tanam 2 tanah : 1 pupuk kandang dan konsentrasi mol 20\% $\left(\mathrm{P}_{3}\right)$ mampu menghasilkan $\mathrm{N}$ yang cukup. Pada fase vegetatif memerlukan unsur $\mathrm{N}$ yang lebih dominan dibandingkan unsur P. Diduga peningkatan pertumbuhan pada fase pembibitan didukung oleh tingginya kandungan unsur $\mathrm{N}$ dalam bahan organik pada pupuk kandang dan kecukupan konsentrasi mol yang digunakan.

\section{KESIMPULAN DAN SARAN}

Media tanam berpengaruh tidak nyata terhadap tinggi bibit, diameter pangkal batang, jumlah daun, berat berangkasan basah dan berat berangkasan kering. Media tanam terbaik untuk pertumbuhan bibit kakao cenderung ditunjukkan pada media tanam 2 tanah : 1 pupuk kandang. 
Konsentrasi mol berpengaruh sangat nyata terhadap jumlah daun pada umur 12 MST dan tidak berpengaruh nyata terhadap parameter tinggi bibit, diameter pangkal batang, berat berangkasan basah dan berat berangkasan kering. Konsentrasi mol terbaik untuk pertumbuhan bibit kakao dijumpai pada konsentrasi mol $30 \%$.

Terdapat interaksi yang nyata antara media tanam 2 tanah : 1 pupuk kandang (kontrol) dan konsentrasi mol 20\% terhadap parameter jumlah daun umur 12 MST yang diteliti, Kombinasi terbaik untuk pertumbuhan bibit kakao dijumpai pada perlakuan media tanam kontrol (2 tanah : 1 pupuk kandang) dan konsentrasi mol 20\%.

Berdasarkan hasil penelitian yang telah dilakukan disarankan untuk tidak menambahkan sekam bakar pada media tanam untuk bibit kakao karena dapat membuat media tanam terlalu lepas dan gembur sehingga menurunkan kapasitas ketersediaan air di media pembibitan.

\section{DAFTAR PUSTAKA}

Agustina, L. 1990. Dasar Nutrisi Tanaman. Rineka Cipta. Jakarta.

Aminah, S. I., M. Nora dan N. Amir. 2015. Pengaruh komposisi media tanam terhadap pembibitan tanaman kakao (Theobroma cacao L.) di polybag. Klorofil. 20: 9092.

Geovani. R. B. 2016. Pertumbuhan bibit kakao (Theobroma cacao L.) dengan pemberian abu janjang kelapa sawit dan pupuk NPK pada medium gambut. Jom Faperta. 2(3): 1-12.

Hakim, N., Y. Nyakpa, A.M. Lubis, S.G. Nugroho, M.R. Saul, M.A. Diha, G.B. Hong dan H.H. Bayley. 2005. Dasar-dasar Ilmu Tanah Lampung : Universitas Lampung.

Gale, N. V., Sackett, T. E., Thomas, S. C. (2016). Thermal treatment and leaching of biochar alleviates plant growth inhibition from mobile organic compounds. PeerJ. 4:e2385. http://dx.doi.org/10.7717/peerj.2385

Kurnia. D. S., I. Anas., S. Anwar dan S. Yahya. 2017. Pengaruh pupuk organik dan arang hayati terhadap kualitas media pembibitan dan pertumbuhan bibit kakao. Jurnak Industrial and Bevarage Crops. 2(4): 107-120.

Lindawati, N., Izhar dan H. Syafria. 2000. Pengaruh pemupukan nitrogen dan intervalnya. JPPTP 2(2): 130-133.

Maria, C. W. 2018. Pengaruh pupuk organik cair bonggol pisang kepok pada tanaman hortikultura. 2018. Jurnal Agrotek. 1 (2): 189-184.

Oktiningtyas, L. Y. 2015. Efektifitas mikroorganisme lokal (mol) kulit pisang dan bonggol pisang terhadap pertumbuhan tanaman selada (Lactuca sativa L.) pada media hidroponik. Naskah Publikasi. Universitas Muhammadiyah Surakarta. 
Peraturan Menteri Pertanian. 2011. Pembenah Tanah Untuk Pemulihan Tanah Sakit. http://litbang.pertanian.go.id/artikel/one/165/pdf/Bahan\%20Pembenah\%20Tana h\%20:\%20Prospek\%20dan\%20Kendala\%20Pemanfaatannya.pdf. Diakses tanggal: 13 November 2018.

Pinem, A. 2011. Pengaruh media tanam dan pemberian kapur terhadap pertumbuhan kakao (Theobroma cacao L.) di pembibitan. Jurnal Agroland. 17(2): 138143.

Purwasasmita, M. 2009. Mikroorganisme Lokal sebagai Pemicu Siklus Kehidupan dalam Bioreaktor Tanaman. Seminar Nasional Teknik Kimia. Bandung 19-20 Oktober 2009. Indonesia. Jakarta.

Pusat Penelitian Kopi dan Kakao Indonesia. 2004. Panduan Lengkap Budidaya Kakao. Agromedia Pustaka. Jakarta.

Rosmarkam, A. dan N. W. Yuwono. 2002. Ilmu Kesuburan Tanah. Kanisius. Yogyakarta.

Roro, K. 2015. Penggunaan mol bonggol pisang (Musa paradisiaca) sebagai dekomposer untuk pengomposan tandan kosong kelapa sawit. Jurnal Ziraah. 40(1): 40-45.

Ruhnayat. 2007. Penentuan kebutuhan pokok unsur hara N, P dan K untuk pertumbuhan tanaman vanili (Vanilla planiofolia). Buletin Penelitian Tanaman Rempah dan Obat. 18 (1).45-59.

Satyawibawa, I dan Y. E. Widyastuti. 1992. Kelapa Sawit Usaha Budidaya, Pemanfaatan Hasil dan Aspek Pemasaran. Penebar Swadaya. Jakarta.

Setyaningsih, I. N. Lailiati dan L. Panggabean. 2009. Pola pertumbuhan Chaetoceros gracilis dalam medium NPSI dan produksi antibakteri. Jurnal Kelautan Nasional. 13(2):25-29.

Sidabutar, S. V. B. Siagian dan Meiriani. 2013. Respon pertumbuhan bibit kakao (Theobroma cacao L.) terhadap pemberian abu janjang kelapa sawit dan pupuk urea pada media pembibitan. Jurnal Online Agroteknologi. 1(4) : 1343-1351.

Siregar, T. H., S. Riadi dan L. Nuraeni. 2004. Budidaya, Pengolahan, dan Pemasaran Coklat. Penebar Swadaya. Jakarta.

Sisworo, W. H. 2006. Swasembada pangan dan pertanian berkelanjutan tantangan abad dua satu: Pendekatan ilmu tanah tanaman dan pemanfaatan iptek nuklir. Jurnal Ilmiah. 11: 43-4.

Suryani, D dan Zulfebriansyah. 2007. Komoditas Kakao : Potret dan Peluang Pembiayaan.

Ekonomi.http://protan.studentjournal.ub.ac.id/index.php/protan/article/view/292.

Diakses pada tanggal 06 Maret 2018.

Pengaruh Media Tanam dan Penggunaan Mol Bonggol Pisang terhadap Pertumbuhan Bibit Kakao (Theobroma cacao L.) (Datul Fadillah, Trisda Kurniawan, Erida Nurahmi) 
Suryani, M. Hatta dan H. Har. 2006. Pengujian media tanam dan pupuk M-17 pada pertumbuhan bibit kakao. Floratek. 2: 19-27.

Sutedjo, M. M. 2002. Pupuk dan Cara Penggunaan. Rineka Cipta. Jakarta.

Tarigan, L., S. E. Ferry dan L. R. Ratna. 2014. Respon pertumbuhan bibit kakao (Theobroma cacao L.) terhadap pemberian pupuk kandang dan pupuk organik cair. Jurnal Online Agroteknologi. 2(4): 1614-1626.

Wahyudi, T. dan P. Rahardjo. 2009. Sejarah dan Prospek dalam Kakao: Manajemen Agribisnis dari Hulu hingga Hilir. Penebar Swadaya. Jakarta.

Widyati, E. 2013. Pentingnya keragaman fungsional organisme tanah terhadap produktivitas lahan. Jurnal Penelitian. Bogor.

Winaldy, J. S., Irsal dan J. Ginting. 2016. Respons pertumbuhan bibit kakao (Theobroma cacao L.) terhadap beberapa komposisi media tanam dan frekuensi penyiraman. Jurnal Agroekoteknologi. 4(4): 2324-2330.

Zulfahri, G., M. H. Nasution dan I. A. Mahbub. 2017. Respon pertumbuhan bibit kakao (Theobroma cacao L.) terhadap pemberian biochar sekam padi dan kompos kulit kopi pada tanah sub soil di polybag. Repository Universitas Jambi. Jambi.1-8. 